Review of OSKAR COX JENSEN, DAVID KENNERLEY, AND IAN NEWMANN (eds). Charles Dibdin and Late Georgian Culture. Pp. xxvi + 249. Oxford: Oxford University Press, 2018. Cloth, £55.

Cunningham, John

\title{
Review of English Studies
}

DOI:

10.1093/res/hgy090

Published: 01/04/2019

Peer reviewed version

Cyswllt i'r cyhoeddiad / Link to publication

Dyfyniad o'r fersiwn a gyhoeddwyd / Citation for published version (APA):

Cunningham, J. (2019). Review of OSKAR COX JENSEN, DAVID KENNERLEY, AND IAN NEWMANN (eds). Charles Dibdin and Late Georgian Culture. Pp. xxvi +249 . Oxford: Oxford University Press, 2018. Cloth, £55. Review of English Studies, 70(294), 371-373.

https://doi.org/10.1093/res/hgy090

\section{Hawliau Cyffredinol / General rights}

Copyright and moral rights for the publications made accessible in the public portal are retained by the authors and/or other copyright owners and it is a condition of accessing publications that users recognise and abide by the legal requirements associated with these rights.

- Users may download and print one copy of any publication from the public portal for the purpose of private study or research.

- You may not further distribute the material or use it for any profit-making activity or commercial gain

- You may freely distribute the URL identifying the publication in the public portal ?

Take down policy

If you believe that this document breaches copyright please contact us providing details, and we will remove access to the work immediately and investigate your claim. 
Oskar Cox Jensen, David Kennerley, And IAn Newmann (eds). Charles Dibdin and Late Georgian Culture. Pp. xxvi + 249. Oxford: Oxford University Press, 2018. Cloth, £55.

Charles Dibdin (1745-1814) was one of the most prolific and important English composers of the late eighteenth and early nineteenth centuries. His oeuvre is so massive that there is no satisfactory modern worklist, yet beyond 'Tom Bowling' his music is rarely performed today. He was also a singer, librettist, painter, stage historian, publisher, travel writer, and auto-biographer: as such he has great significance not only for theatre and music histories but for cultural history in general. However, with few exceptions, he remains a peripheral character in historical narratives. The only monograph-length study dedicated to Dibdin was published almost 30 years ago (Robert Fahrner, 1989). This new edited collection is thus welcome and timely. Its origins lie in the AHRC project 'Music in London, 1800-51'; as a fitting tribute to Dibdin, it brings together 'experts in the fields of art, history, literature, music, and theatre' (p.19). Indeed, its value lies in the multiplicity of topics and approaches, but most of all the essays largely place Dibdin in a central position in the narrative of the late- eighteenth and early nineteenth centuries.

The book is organized in three parts: (I) Dibdin in Context; (II) Songs in Focus; (III) NineteenthCentury Transitions. Prefacing these sections is a chapter, by the editors, 'Introducing Mr Dibdin', in which they convincingly conclude (with reference to William Weber's 2008 monograph on musical taste) that rather than see Dibdin as an expression of 'the larger cultural movement towards specialization that began in his day and which continues to shape our current academic environment' (p.19) it is precisely this focus on specialization that explains why Dibdin has remained neglected (an idea echoed in Mark Philip's afterword). This is true to a point but overlooks the real practical boundaries: i.e. the sheer scale of his output and the way in which it survives.

In the opening essay of part I, Felicity Nussbaum discusses the way in which many of Dibdin's comic musical dramas present slavery and captivity to humorous effect. Most obvious is the role of Mungo in Bickerstaff's The Padlock (1768), which gave Dibdin his big break on the London stage. He wrote the music and delivered the role of the Afro-Caribbean slave in blackface: a novelty in his time; problematic in ours. Nussbaum effectively argues that such roles 'reflect without resolving' (p.23), the cultural dissonance created by slavery and colonial expansion. Michael Burden explores one of the lesser-known, and most fascinating, aspects of Dibdin's multifarious career: the Royal Circus. Opened in 1782 in partnership with Charles Hughes and Philip Astley, the RC offered equestrian entertainments alongside miscellaneous stage works, mostly acted by children. Here Burden sheds important new light on 'the cutthroat world of the London minor theatres' (p.43) and the pressures that drove them. By February 1784 Dibdin was voted out by the proprietors. Indeed, the 
venture perhaps highlights the best and worst of Dibdin: his ability (and willingness) to innovate and his inability to successfully navigate business relationships for any sustained period.

There follows the first of three short Interludes. Katie Osborn looks at Dibdin alongside the poet Robert Bloomfield, suggesting that both 'used dialect and rusticity ... to assert themselves as independent comic voices' (p.60): a reasonable suggestion, but dealt with all too briefly. In the following essay, David O'Shaughnessy explores Dibdin's patriotism through his short-lived periodical The Devil (1786-7), emphasising the increasingly modern role of the media in the construction of the public persona in the period. The result is a skilful examination of Dibdin as a social commentator: rooted in ideals of patriotism, Dibdin set himself in opposition to newspapers and theatres, which he saw as foregoing their public duty by bending to commercialism. David Kennerley continues along the same theme, exploring Dibdin's self-fashioning in the 1790s. He argues that the composer's cultivation of a public persona in the late 1780s was centred on 'his supposed naturalness, sincerity, independence, and manliness' (p.79). These traits were at the heart of this oneman-shows, the 'table entertainments', of the 1790s. Moreover, this conscious self-fashioning motivated, for example, Dibdin's pursuit of libel actions in response to attacks in the press. In the final chapter of part I, Judith Hawley enquires why Dibdin was attracted to the experimental (and potentially risky) genre of the table entertainment as a performance medium, in the context of private theatricals; her impressive exposition is achieved partly though the agency of one of the many volumes of text (in Dibdin's spidery hand) in the British Library. Part I concludes with an interlude by Nicola Pritchard-Pink teasing us with a frustratingly brief introduction to Jane Austen's songbook, in which Dibdin is the best-represented composer.

Part II moves from context to case studies centred on individual songs. Oskar Cox Jensen offers a fascinating exegesis of the song 'True courage' (1798): the only chapter that really deals with Dibdin's music as music to any extent (there is even a link to a decent recording). The essay uses the song - pressed service as loyalist propaganda - as an example of how Dibdin's sea songs can (and indeed need to be) be understood from a range of perspectives: composition, performance (in a table entertainment), commercialism, dissemination, and reception. Harriet Guest turns the focus to the ballad 'The Margate Hoy' from Dibdin's 1795 Christmas Gambols (a recent recording is available by Retrospect Opera). Emphasising the interconnectedness of cultural artefacts, Guest explores (supported by fourteen illustrations) how the song 'draws on well-established visual types', including caricatures 'as much as theatrical and textual sources' (p.157). In the final interlude, Nicholas Grindle explains how in the 1790s several of Dibdin's song characters became the subjects of 'posture' prints. The lengthiest of the interludes, Grindle is able to explore in reasonable depth the relationship between Dibdin 
and John Raphael Smith, showing how the more sophisticated and expensive visual representations of Dibdin's songs can further our understanding of his socio-cultural context.

The first two essays of Part III deal with Dibdin's sons, with whom he had a strained relationship. Susan Valladares offers an insight to the final years of Charles the Younger's almost twenty-year management of the Sadler's Wells Theatre. Valladares uses Charles the Younger's memoirs to great effect in foregrounding the vicissitudes of theatrical management, with which his father was all too familiar. Jim Davis throws into relief the other, other Dibdin, Thomas, who achieved success as a playwright in the first quarter of the nineteenth century. Davis carefully constructs the case that Dibdin was of particular value because of his ability to create memorable roles for specific actors; in doing so he reveals how 'the dramatic text was not sacrosanct but merely one aspect of a collaborative approach to creating performance' (p.202): ultimately Thomas's downfall. The final essay returns to Dibdin pater. Isaac Land offers an intriguing account of Dibdin's reception in the later nineteenth century, explaining how the Victorians engaged with Dibdin and his oeuvre, as he became on object of serious study and as his patriotic sea songs enjoyed a renewed appreciation in the final decades; all of which required a renegotiation of the rougher edges of Dibdin's life and language.

The essays are well-written and researched, though one wishes that the interludes were developed into full chapters. The frequent cross-referencing adds to a sense of continuity. The volume is a most welcome contribution: hopefully it stimulates further research.

The editors begin their Acknowledgements noting that 'There is a chance that Charles Dibdin would have approved of this book'. I think he would, too. He even probably would have some sympathy for OUP's off-putting price point. 